\title{
Mechanisms of Neurogenic Pulmonary Edema Development
}

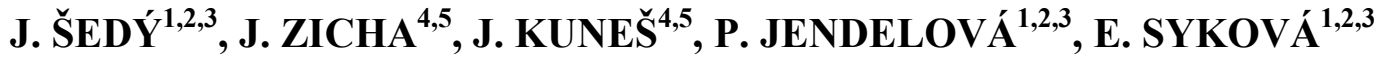 \\ ${ }^{1}$ Institute of Experimental Medicine, ASCR, Prague, ${ }^{2}$ Center for Cell Therapy and Tissue Repair, \\ Second Faculty of Medicine, Charles University, Prague, ${ }^{3}$ Department of Neuroscience, Second \\ Faculty of Medicine, Charles University, Prague, ${ }^{4}$ Institute of Physiology, ASCR, Prague and \\ ${ }^{5}$ Center for Cardiovascular Research, Prague, Czech Republic
}

Received September 18, 2007

Accepted October 19, 2007

On-line November 30, 2007

\begin{abstract}
Summary
Neurogenic pulmonary edema is a life-threatening complication, known for almost 100 years, but its etiopathogenesis is still not completely understood. This review summarizes current knowledge about the etiology and pathophysiology of neurogenic pulmonary edema. The roles of systemic sympathetic discharge, central nervous system trigger zones, intracranial pressure, inflammation and anesthesia in the etiopathogenesis of neurogenic pulmonary edema are considered in detail. The management of the patient and experimental models of neurogenic pulmonary edema are also discussed.
\end{abstract}

\section{Key words}

Neurogenic pulmonary edema $\bullet$ Rat $\bullet$ Model $\bullet$ Lung $\bullet$ Spinal cord injury

\section{Corresponding author}

E. Syková, Institute of Experimental Medicine ASCR, Vídeňská 1083, 14220 Prague 4, Czech Republic. FAX: +420-241062782. E-mail: sykova@biomed.cas.cz

\section{Introduction}

Neurogenic pulmonary edema is an acute lifethreatening complication of severe central nervous system injury. Although long neglected in clinical practice, it has been recognized scientifically for many years; the first report comes from Shanahan (1908). Neurogenic pulmonary edema develops rapidly following the injury and significantly complicates the overall clinical status of the patient. It is characterized by marked pulmonary vascular congestion with perivascular edema, extravasation and intra-alveolar accumulation of proteinrich edema fluid and intraalveolar hemorrhage (Kandatsu et al. 2005, Leal Filho et al. 2005a, b). Although several pathophysiological mechanisms have been proposed, the exact cascade leading to the development of neurogenic pulmonary edema remains unclear (Leal Filho et al. $2005 a, b)$. Both the release of vasoactive substances and a rapid, transient, and severe sympathetic discharge are thought to participate in this process (Urdaneta and Layon 2003). The aim of this review is to summarize the known data about the pathophysiology of neurogenic pulmonary edema and also highlight the importance of some new data, recently obtained from experimental research of neurogenic pulmonary edema.

\section{Epidemiology of neurogenic pulmonary edema}

Although epidemiological data of neurogenic pulmonary edema are scarce and often based on case reports or epidemiological studies with low numbers of enrolled patients or different diagnostic criteria, we can assume its morbidity in patients with severe central nervous system injury to be $40-50 \%$ and its mortality around 7 \% (Dragosavac et al. 1997, Antoniuk et al. 2001, Fontes et al. 2003). The main reason for the low number of published epidemiological studies is probably the generally poor clinical status of the patient, caused by the primary central nervous system injury, and the 
necessity of rapid and often complex treatment when neurogenic pulmonary edema develops.

\section{Management of patients with neurogenic pulmonary edema}

The signs of neurogenic pulmonary edema are quite non-specific. It presents subjectively with a sudden onset of dyspnea, chest pain, worsening of expectoration, nausea, vomitting, weakness and an awareness of the patient's own life. During the clinical examination, one finds tachypnoe, tachycardia, basal bilateral pulmonary crackles, respiratory distress or failure, expectoration of sanguinolent sputum or even hemoptysis, hypoxemia, increased systemic blood pressure and decreased heart rate, consciousness disturbances, and pulmonary edema with normal jugular venous pressure (Baumann et al. 2007). Some authors describe a so-called "death rattle" (Fontes et al. 2003). Importantly, no or very few signs of inflammation are present. The most relevant imaging method is the chest X-ray examination, where diffuse hyperintensive infiltrates in both lungs are apparent. The transient increase in pulmonary artery occlusion pressure is usually not found due to the very short duration of its increase and the delay in measurement (Ganter et al. 2006). Although the levels of some substances such as brain natriuretic peptide, blood C-reactive protein and IL6 are increased, unfortunately none of these can be used as a marker specific for neurogenic pulmonary edema (Baumann et al. 2007). Treatment is based primarily on ventilation with positive end-expiratory pressure and support of the patient's general health status. Other treatment modalities are still under debate among clinicians and scientists (Baumann et al. 2007).

\section{Role of central nervous system damage or injury in the development of neurogenic pulmonary edema}

Neurogenic pulmonary edema has been described following several central nervous system injuries, including spinal cord injury, subarachnoid hemorrhage, primary spinal cord hemorrhage, brain trauma, intracerebral bleeding, severe epileptic grand mal seizure or subdural hematoma (Simmons et al. 1969, Dragosavac et al. 1997, Ochiai et al. 2001, Macleod et al. 2002, Fontes et al. 2003, Seric et al. 2004, Baumann et al. 2007). There are two possible explanations for the association of the edema with central nervous system injury. One presumes that the neuronal damage directly or indirectly involves the pulmonary vascular bed. The most probable mechanisms of such involvement are a temporary neural commotion or either a mechanical or electrophysiological disconnection of the central nervous system vasomotor centres, which leads to the destabilization of the pulmonary autonomic nervous system (Fontes et al. 2003, Baumann et al. 2007). The overstimulation of the vasomotor centres might be an alternative explanation. This is supported by the fact that severe central nervous system injury is always associated with significant changes in autonomic nervous system function (Leal Filho et al. 2005a,b, Šedý et al. 2007a,c). The function of specific neurons of the central nervous system must be impaired during brain or spinal cord injury to destabilize the autonomic system balance so that an imbalance of Starling forces in the pulmonary vascular bed occurs and neurogenic pulmonary edema may develop (Šedý et al. 2008).

Numerous experiments have shown that some interventions in the brain or spinal cord are able to stimulate the peripheral sympathetic nervous system and to produce changes in blood pressure (Guyenet 2006). These data indicate that the central nervous system sympathetic centers (including trigger zones for neurogenic pulmonary edema) might be influenced by such manipulations. It has been observed that experimental brainstem distortion or ischemia can cause changes of sympathetic vasomotor tone and an increase of blood pressure. Moreover, the elevation of blood pressure and the subsequent development of neurogenic pulmonary edema can be prevented by the intrathecal administration of lidocaine (Guyenet 2006, Hall et al. 2002).

\section{Trigger zones of neurogenic pulmonary edema}

Several experimental studies have indicated that the neurons responsible for the severe sympathetic discharge, the most probable cause of neurogenic pulmonary edema, are located in the hypothalamic, brainstem and cervical spinal cord nuclei. These centers represent so-called neurogenic pulmonary edema trigger zones (Baumann et al. 2007), and their arrangement corresponds to the organotopy hypothesis (for review see Guyenet 2006). The most important vasomotor centers for neurogenic pulmonary edema development are thought to be the A1 and A5 groups of neurons, nuclei of 
the solitary tract, the area postrema, the medial reticulated nucleus and the dorsal motor vagus nucleus in the medulla oblongata. Some hypothalamic centers (paraventricular and dorsomedial nuclei) also seem to be of some importance. It can be assumed that $\mathrm{C} 1$ adrenaline-synthesizing neurons, definitely identified as a key blood pressure centre (for review see Guyenet 2006), are responsible for the observed sympathetic activation. Interestingly, casualties from the Vietnam war who had concomitant brain injury and cervical spinal cord injury did not develop neurogenic edema, whereas the majority of casualties with brain injury alone developed edema (Simmons et al. 1969). In the first group, the trigger zones were probably disconnected from the rest of the body by cervical spinal cord transection.

In experiments on rabbits, bilateral lesions of the nuclei in the medulla oblongata produced profound pulmonary and systemic hypertension and pulmonary edema (Blessing et al. 1981). The increased intracranial pressure as well as toxic or ischemic injury of inhibitory neurons cause excessive sympathetic neuronal activity (severe sympathetic discharge) and the release of vasoactive substances such as epinephrine, norepinephrine, endothelins or neuropeptide $\mathrm{Y}$ into the circulation, leading to the development of neurogenic pulmonary edema (Poulat et al. 1998, Hamdy et al. 2000 Baumann et al. 2007). For example, neuropeptide $\mathrm{Y}$ has been found in alveolar macrophages and edema fluid in the case of neurogenic pulmonary edema, but not in rats with hydrostatic edema (Hamdy et al. 2000). Alphaadrenergic blockade (with phentolamine) or spinal cord transection at the $\mathrm{C} 7$ level prevents the formation of neurogenic pulmonary edema, suggesting an important role for sympathetic activation (Nathan et al. 1975). In addition, the inhibition of central nervous system nitric oxide by the injection of a competitive inhibitor of $\mathrm{NO}$ syntase, NG-nitro-L-arginine methyl ester (L-NAME), into the cisterna magna worsened the extent of development of neurogenic pulmonary edema (Hamdy et al. 2001).

\section{Neurogenic pulmonary edema develops on the basis of intracranial pressure increase}

After central nervous system injury, a prominent hemorrhage into different compartments that correspond to the epidural, subdural, subarachnoid and intramedular (intracerebral) spaces and consequent damage to the blood-brain barrier occur. In clinical situations such as subdural or subarachnoid hemorrhage, the extravasation of blood into the corresponding compartments is the major mechanism. Walder et al. (2002) showed that the amount but not the type of fluid injected intrathecally had a significant impact on hemodynamic and respiratory parameters. The main disadvantage of any intracranial or intraspinal hemorrhage is the very rapid increase of intracranial pressure inside a non-expandable bony space with rather limited mechanisms to decrease it. This pressure increase leads to the compression of nervous tissue, resulting in a brainstem distortion or ischemia and later even in cerebral herniation. It has been shown in experiments on sheep that the elevation of intracranial pressure increases pulmonary artery pressure, cardiac output, lung lymph flow, permeability-surface area product and extravascular lung water volume (Peterson et al. 1983). This seems to be due to elevated venous return due to excess sympathetic venoconstriction. In addition, when the intracranial pressure is suddenly elevated by subdural balloon inflation, neurogenic pulmonary edema develops (Hall et al. 2002).

Our experiments with a model of severe neurogenic pulmonary edema, elicited by an epidural balloon compression spinal cord lesion under lower concentrations of isoflurane anesthesia, strongly support the crucial role of intracranial hypertension in the development of neurogenic pulmonary edema (Šedý et al. 2007b). When the balloon is rapidly inflated in the enclosed space of the thoracic part of the spinal channel, the rapid increase in intracranial pressure apparently has an etiopathogenic role in the development of neurogenic pulmonary edema (Šedý et al. 2007a,c). This suggestion is supported by our recent findings that other types of thoracic spinal cord lesions such as transection, hemisection or contusion do not lead to the development of neurogenic pulmonary edema (Šedý et al. unpublished data).

\section{Inflammation is not involved in the development of neurogenic pulmonary edema}

The most frequent form of neurogenic pulmonary edema, the so-called "early form", usually develops within minutes or, at the most, hours after the injury (Simmons et al. 1969, Seric et al. 2004, Guyenet 2006, Baumann et al. 2007). In our experiments with spinal cord-injured rats, the full picture of neurogenic pulmonary edema developed within 5-12 minutes from 
the onset of our intervention on the spinal cord (Šedý et al. 2007a,b,c). It should be pointed out that the cascade of the inflammatory response, which would be able to cause such extravasation of intravascular fluid together with the damage of blood vessel walls leading to intraalveolar hemorrhage, will take a longer time, as in acute respiratory distress syndrome (Gattinoni et al. 1993). It is true that some exogenous substances causing the initiation of an allergic reaction cascade might induce a rapid inflammatory reaction leading to the extravasation of fluid and the development of edema, but neurogenic pulmonary edema is not such a case. In addition, spinal cord injury does not initiate any systemic inflammatory response, as demonstrated by the lack of any damage to other organs except the lungs (Šedý et al. 2007a).

\section{Role of the sympathetic system in the development of neurogenic pulmonary edema}

Many experiments have shown, directly or indirectly, that the sympathetic nervous system has a major responsibility for neurogenic pulmonary edema development. It has been shown using animal models of neurogenic pulmonary edema that changes in systolic and diastolic pressure together with heart rate alterations indicate a rapid systemic activation of the sympathetic nervous system, which has been termed "severe sympathetic discharge" or "catecholamine storm" (Taoka and Okajima 1998, Fontes et al. 2003, Urdaneta and Layon 2003). The catecholamine storm has its parallel in the older "blast theory" of Theodore and Robin (1976), which proposes that a neurally induced transient rise in intravascular pressure may damage the endothelium, causing protein-rich plasma to escape into the interstitial and alveolar spaces. The overactivation of the sympathetic nervous system is associated with the enhanced secretion of catecholamines from peripheral sympathetic nerve endings, which leads to peripheral vasoconstriction, an increase in systemic vascular resistance and subsequently to an increase in systemic blood pressure together with the augmentation of central blood volume and a reduction in the compliance of the left ventricle. These changes are followed by the constriction of the pulmonary veins, an increase in pulmonary capillary hydrostatic pressure, damage to the alveolar wall and the leakage of fluid into the interstitium and intraalveolar space and hemorrhage resulting in the typical picture of neurogenic pulmonary edema.

\section{Dose-dependent influence of anesthesia on the development of neurogenic pulmonary edema}

Systemic anesthesia is accompanied by the inhibition of both spontaneous and evoked activity of neurons. The first phase of systemic anesthesia is characterized by the inhibition of the activity of cortical neurons, whereas deep anesthesia leads to the partial inhibition of subcortical neurons, probably also including the sympathetic ones. When we used $1.5 \%$ isoflurane (when severe neurogenic edema develops) instead of $3 \%$ isoflurane (where no edema develops) for performing a spinal cord lesion in rats, the baseline mean arterial pressure and heart rate values were significantly increased. In addition, animals anesthetized with lower concentration of isoflurane anesthesia exhibited higher "cardiovascular reactivity", in terms of blood pressure and heart rate changes, to any of the particular procedures during the whole surgery (Šedý et al. 2007a,c). Leal Filho et al. $(2005 \mathrm{a}, \mathrm{b})$ performed similar experiments, but they used pentobarbital or a ketamine-xylazine mixture for anesthetising rats in which a balloon compression lesion was made. They observed severe neurogenic pulmonary edema in pentobabital-anesthetized rats and borderline neurogenic edema in rats anesthetized with ketaminexylazine. The systolic blood pressure in pentobarbitalanesthetized rats rose to twice the baseline values, whereas it was only $13 \%$ higher in ketamine-xylazine rats (Leal Filho et al. 2005a, b), indicating that the pentobarbital-anesthetized rats responded more strongly to spinal compression. However, these authors did not perform dose-response experiments and used only one concentration of each type of anesthetic (pentobarbital 60 $\mathrm{mg} / \mathrm{kg}$; ketamine-xylazine $75 \mathrm{mg} / \mathrm{kg}$ and $10 \mathrm{mg} / \mathrm{kg}$, respectively). Perhaps lower doses of ketamine-xylazine would be able to promote severe neurogenic pulmonary edema also. Similarly, higher doses of pentobarbital would be able to prevent its development. The extreme differences in response to different concentrations of isoflurane ( $3 \%$ - no edema vs. $1.5 \%$ - massive edema) seen in our experiments strongly support such hypothesis (Šedý et al. 2007a,c).

The above data indicate the necessity to maintain precisely the same level of anesthesia during experimental central nervous system manipulations, such as brain or spinal cord injury models (Vanický et al. 2001, Syková et al. 2005a), the injection of particular substances into the central nervous system parenchyma 
(Syková et al. 2005b, 2006), neurosurgical manipulations such as the implantation of hydrogel scaffolds (Lesný et al. 2002), the preparation of animal models of epilepsia (Bender et al. 2004) and many others. For these purposes, the anesthesia should be precisely and reproducibly dosed. Although this is quite simple with volatile anesthetics such as isoflurane or sevoflurane (Kandatsu et al. 2005, Šedý et al. 2007a), it might be more difficult when intravenous anesthetics such as pentobarbital or ketamine-xylazine are used (Leal Filho et al. 2005a,b). If possible, intravenous anesthetics should be avoided in experiments in which central nervous system tissue is surgically manipulated or the intracranial pressure is changed. If this is not possible, the infusion rate of the anesthetic solution should be carefully controlled.

In the future, clinical studies might show that during the acute phase (minutes to hours) after central nervous system injury, the maintenance of patients under anesthesia might be helpful in preventing the development of neurogenic pulmonary edema. Presently, no intervention to prevent the development of neurogenic pulmonary edema is known. For example, the blockade of the sympathetic nervous system (Šedý et al. 2007a) or the intrathecal injection of lidocaine (Hall et al. 2002), which are used in experiments to prevent the development of neurogenic pulmonary edema, would probably not be advisable in human medicine. In addition, any other total or partial modulation of the sympathetic nervous system that would positively influence neurogenic pulmonary edema development might also significantly worsen the clinical status of the patient.

\section{Experimental models of neurogenic pulmonary edema}

Today, many models of neurogenic pulmonary edema are used in experimental studies. In these models, the pulmonary edema is induced either by central nervous system injury (Leal Filho et al. 2005a,b, Šedý et al. 2007b) or by the administration of exogenous substances into the cerebrospinal fluid or directly into the nervous tissue (Hamdy et al. 2000, 2001, Walder et al. 2002). In rats, the injection of fibrin (fibrinogen + thrombin) into the cisterna magna has been reported to induce pulmonary edema (Ishikawa et al. 1988). In dogs, the injection of verathrin (Lane et al. 1998, Maron 1985), and in sheep, the injection of aconitine (Minnear and Connell 1981), both into the cisterna magna, are also able to induce neurogenic pulmonary edema. However, the development of neurogenic pulmonary edema in these types of models has been considered to result from a cholinergic-mediated increase in vascular permeability (Bosso et al. 1990) rather than from severe sympathetic discharge, the most suspected cause of neurogenic pulmonary edema development in human patients (Fontes et al. 2003). Another model of pulmonary edema in dogs uses an intravenous injection of oleic acid (Dauber and Weil 1983). Pulmonary edema can also be caused by the intravenous administration of epinephrine, which stimulates vasoconstriction (Dai et al. 1993a,b), or bilateral cervical vagotomy, which inhibits vasodilatation (Iazzetti et al. 1988). Although the sympathetic nervous system is almost surely involved in the development of pulmonary edema after the administration of an exogenous substance, we propose that neurogenic pulmonary edema should always be induced by central nervous system injury in future experiments in order to ensure that the edema is, in fact, "neurogenic" in origin.

\section{Conclusions}

Neurogenic pulmonary edema is a rapidly developing, life-threatening complication of central nervous system injuries. It significantly worsens the general health status of the patient. For neurogenic pulmonary edema, the rapid onset of dyspnea and several other non-specific signs are typical. Most valuable for diagnosis is a chest X-ray, while the most valuable modality in treatment is ventilation with positive-end expiratory pressure. A specific marker for neurogenic pulmonary edema has not yet been found, and a specific treatment protocol has not yet been developed. Most probably, such edema develops on the basis of a rapid systemic sympathetic discharge, leading to pulmonary vascular congestion with perivascular edema, extravasation and the intra-alveolar accumulation of protein-rich edema fluid and intraalveolar hemorrhage. There exists evidence that intracranial pressure is also of some importance. The level of anesthesia might be crucial for the extent of neurogenic pulmonary edema development. There are several models of neurogenic pulmonary edema; however, those in which neurogenic pulmonary edema is induced by central nervous system injury should be preferred.

\section{Conflict of Interest}

There is no conflict of interest. 


\section{Acknowledgements}

We thank James Dutt for critical reading of the manuscript. We acknowledge the support provided by the grants AV0Z50390512, AV0Z50110509, 1M0538,
LC554, GACR309/06/1246, IGA MZ 1A8697-5, IGA MZ NR/8339-3, 1M0510 and the EC FP6 project RESCUE (LSHB-CT-2005-518233).

\section{References}

ANTONIUK SA, OLIVA AV, BRUCK I, MALUCELLI M, YABUMOTO S, CASTELLANO JL: Sudden unexpected, unexplained death in epilepsy autopsied patients. Arq Neuropsiquiatr 59: 40-45, 2001.

BAUMANN A, AUDIBERT G, MCDONNEL J, MERTES PM: Neurogenic pulmonary edema. Acta Anaesthesiol Scand 51: 447-455, 2007.

BENDER RA, DUBE C, BARAM TZ: Febrile seizures and mechanisms of epileptogenesis: insights from an animal model. Adv Exp Med Biol 548: 213-225, 2004.

BLESSING WW, WEST MJ, CHALMERS J: Hypertension, bradycardia, and pulmonary edema in the conscious rabbit after brainstem lesions coinciding with the A1 group of catecholamine neurons. Circ Res 49: 949-958, 1981.

BOSSO FL, LANG SA, MARON MB: Role of hemodynamics and vagus nerves in development of fibrin-induced pulmonary-edema. J Appl Physiol 69: 2227-2232, 1990.

BULLOCK R, FUJISAWA H: The role of glutamate antagonists for the treatment of CNS injury. $J$ Neurotrauma 9: 443-473, 1992.

DAI S, XUE Q, SUN R, WANG S, LI C, WU Y, SI Q, HU S: Hemodynamic and nonhemodynamic mechanisms of experimental pulmonary edema in rats and the effect of anisodamine and tetramethylpyrazine. Part 1: Survival rate, pulmonary index, pathological change and pulmonary vascular permeability. Chin Med Sci J 8: 72-76, 1993a.

DAI S, SU S, CAO Y, SUN R, FAN Y, ZHANG H, SI Q, XUE Q: Hemodynamic and nonhemodynamic mechanism of experimental pulmonary edema in rats and the effect of anisodamine and tetramethylpyrazine--electron microscopic observation and measurement of pulmonary arterial, pulmonary arterial wedge and systemic arterial pressure (Part 2). Chin Med Sci J 8: 129-133, 1993 b.

DAUBER IM, WEIL JV: Lung injury edema in dogs. Influence of sympathetic ablation. J Clin Invest 72: 1977-1986, 1983.

DRAGOSAVAC D, FALCAO ALE, ARAÚJO S, TERZI RGG: Neurogenic pulmonary edema: report of two cases. Arq Neuropsiquiatr 55: 305-309, 1997.

FONTES RB, AGUIAR PH, ZANETTI MV, ANDRADE F, MANDEL M, TEIXEIRA MJ: Acute neurogenic pulmonary edema: case reports and literature review. J Neurosurg Anesthesiol 15: 144-150, 2003.

GANTER BG, JAKOB SM, TAKALA J: Pulmonary capillary pressure. A review. Minerva Anestesiol 72: 21-36, 2006.

GATTINONI L, D'ANDREA L, PELOSI P, VITALE G, PESENTI A, FUMAGALLI R: Regional effects and mechanism of positive end-expiratory pressure in early adult respiratory distress syndrome. JAMA 269: 21222127, 1993.

GUYENET PG: The sympathetic control of blood pressure. Nat Rev Neurosci 7: 335-346, 2006.

HALL SR, WANG L, MILNE B, FORD S, HONG M: Intrathecal lidocaine prevents cardiovascular collapse and neurogenic pulmonary edema in a rat model of acute intracranial hypertension. Anesth Analg 94: 948-953, 2002.

HAMDY O, NISHIWAKI K, YAJIMA M, MURAKAMI HO, MAEKAWA H, MOY RT, SHIMADA Y, HOTTA Y, ISHIKAWA N: Presence and quantification of neuropeptide $\mathrm{Y}$ in pulmonary edema fluids in rats. Exp Lung Res 26: 137-147, 2000.

HAMDY O, MAEKAWA H, SHIMADA Y, FENG GG, ISHIKAWA N: Role of central nervous system nitric oxide in the development of neurogenic pulmonary edema in rats. Crit Care Med 29: 1222-1228, 2001.

IAZZETTI PE, MACIEL RE: Effects of hyperbaric oxygen on the rat neurogenic pulmonary edema. Braz J Med Biol Res 21: 153-156, 1988. 
ISHIKAWA N, KAINUMA M, FURUTA T, SATO Y: Factors influencing fibrin-induced pulmonary edema. Jpn $J$ Pharmacol 46: 255-260, 1988.

JAIN R, DEVEIKIS J, THOMPSON BG: Management of patients with stunned myocardium associated with subarachnoid hemorrhage. AJNR Am J Neuroradiol 25: 126-129, 2004.

KANDATSU N, NAN YS, FENG GG, NISHAWAKI K, ISHIKAWA K, KOMATSU T, YOKOCHI T, SHIMADA Y, ISHIKAWA N: Opposing effects of isoflurane and sevoflurane on neurogenic pulmonary edema development in an animal model. Anesthesiology 102: 1182-1189, 2005.

LANE SM, MAENDER KC, AWENDER NE, MARON MB: Adrenal epinephrine increases alveolar liquid clearance in a canine model of neurogenic pulmonary edema, Am J Respir Crit Care Med 158: 760-768, 1998.

LEAL FILHO MB, MORANDIN RC, DE ALMEIDA AR, CAMBIUCCI EC, METZE K, BORGES G, GONTIJO JA: Hemodynamic parameters and neurogenic pulmonary edema following spinal cord injury: an experimental model. Arq Neuropsiquiatr 63: 990-996, 2005a.

LEAL FILHO MB, MORANDIN RC, DE ALMEIDA AR, CAMBIUCCI EC, BORGES G, GONTIJO JA, METZE K: Importance of anesthesia for the genesis of neurogenic pulmonary edema in spinal cord injury. Neurosci Lett 373: $165-170,2005 b$.

LESNÝ P, DE CROOS J, PŘÁDNÝ M, VACÍK J, MICHÁLEK J, WOERLY S, SYKOVÁ E: Polymer hydrogels usable for nervous tissue repair. J Chem Neuroanat 23: 243-247, 2002.

MACLEOD AD: Neurogenic pulmonary edema in palliative care. J Pain Symptom Manage 23: 154-156, 2002.

MARON MB: A canine model of neurogenic pulmonary edema. J Appl Physiol 59: 1019-1025, 1985.

MARON MB: Analysis of airway fluid protein concentration in neurogenic pulmonary edema. $J$ Appl Physiol 62: 470476, 1987.

MESQUITA MB, MORAES-SANTOS T, MORAES MF: Phenobarbital blocks the lung edema induced by centrally injected tityustoxin in adult Wistar rats. Neurosci Lett 332: 119-122, 2002.

MINNEAR FL, CONNELL RS: Increased permeability of the capillary-alveolar barriers in neurogenic pulmonary edema (NPE). Microvasc Res 22: 345-366, 1981.

NATHAN MA, REIS DJ: Fulminating arterial hypertension with pulmonary edema from release of adrenomedullary catecholamines after lesions of the anterior hypothalamus in rat. Cir Res 37: 226-235, 1975.

OCHIAI H, YAMAKAWA Y, KUBOTA E: Deformation of the ventrolateral medulla oblongata by subarachnoid hemorrhage from ruptured vertebral artery aneurysms causes neurogenic pulmonary edema. Neurol Med Chir (Tokyo) 41: 529-534, 2001.

PETERSON BT, ROSS JC, BRIGHAM KL: Effect of naloxone on the pulmonary vascular responses to graded levels of intracranial hypertension in anesthetized sheep. Am Rev Respir Dis 128: 1024-1029, 1983.

POULAT P, COUTURE R: Increased pulmonary vascular permeability and oedema induced by intrathecally injected endothelins in rat. Eur J Pharmacol 344: 251-259, 1998.

ŠEDÝ J, URDZÍKOVÁ L, HEJČL A, BURIAN M, LIKAVČANOVÁ K, JENDELOVÁ P, ZICHA J, KUNEŠ J, SYKOVÁ E: Low concentration of isoflurane promotes the development of neurogenic pulmonary edema in spinal cord injured rats. J Neurotrauma 24: 1487-1501, 2007 a.

ŠEDÝ J, URDZÍKOVÁ L, LIKAVČANOVÁ K, HEJČL A, JENDELOVÁ P, SYKOVÁ E: A new model of severe neurogenic pulmonary edema in spinal cord injured rats. Neurosci Lett 423: 167-171, $2007 \mathrm{~b}$.

ŠEDÝ J, URDZÍKOVÁ L, HEJČL A, BURIAN M, LIKAVČANOVÁ K, JENDELOVÁ P, SYKOVÁ E: Low concentration of isoflurane causes neurogenic pulmonary edema in spinal cord injured rats. Physiol Res 56: 34P, 2007c.

ŠEDÝ J, LIKAVČANOVÁ K, URDZÍKOVÁ L, ZICHA J, KUNEŠ J, HEJČL A, JENDELOVÁ P, SYKOVÁ E: Low degree of anesthesia increases the risk of neurogenic pulmonary edema development. Med Hypotheses 70: 307$313,2008$.

SERIC V, ROJE-BEDEKOVIC M, DEMARIN V: Neurogenic pulmonary edema. Acta Clin Croat 43: 389-395, 2004.

SHANAHAN WT: Acute pulmonary edema as a complication of epileptic seizures. NY Med J 37: 54-56, 1908.

SIMMONS RL, HEISTERKAMP CA, COLLINS JA, BREDENBERG CE, MILLS DE, MARTIN AM: Respiratory insufficiency in combat casualties. IV. Hypoxemia during convalescence. Ann Surg 170: 53-62, 1969. 
SMITH WS, MATTHAY MA: Evidence for a hydrostatic mechanism in human neurogenic pulmonary edema. Chest 111: 1326-1333, 1997.

SYKOVÁ E, URDZÍKOVÁ L, JENDELOVÁ P, BURIAN M, GLOGAROVÁ K, HÁJEK M: Bone marrow cells - A tool for spinal cord injury repair. Exp Neurol 193: 261-262, 2005a.

SYKOVÁ E, JENDELOVÁ P: Magnetic resonance tracking of implanted adult and embryonic stem cells in injured brain and spinal cord. Ann N Y Acad Sci 1049: 146-160, 2005 b.

SYKOVÁ E, JENDELOVÁ P: Magnetic resonance tracking of transplanted stem cells in rat brain and spinal cord. Neurodegener Dis 3: 62-67, 2006.

TAOKA Y, OKAJIMA K: Spinal cord injury in the rat. Prog Neurobiol 56: 341-358, 1998.

THEODORE J, ROBIN ED: Speculations on neurogenic pulmonary edema (NPE). Am Rev Respir Dis 113: 405-411, 1976.

URDANETA F, LAYON AJ: Respiratory complications in patients with traumatic cervical spine injuries: case report and review of the literature. J Clin Anesth 15: 398-405, 2003.

VANICKÝ I, URDZIKOVÁ L, SAGANOVÁ K, ČÍŽKOVÁ D, GÁLIK J. Simple and reproducible model of spinal cord injury induced by epidural baloon inflation of the rat. J Neurotrauma 18: 1399-1407, 2001.

WALDER B, BRUNDLER MA, TOTSCH M, ELIA N, MOREL DR: Influence of the type and rate of subarachnoid fluid infusion on lethal neurogenic pulmonary edema in rats. J Neurosurg Anesthesiol 14: 194-203, 2002. 